\title{
How EPC firms can enter the nuclear renaissance
}

\author{
Giorgio Locatelli \\ University of Lincoln \\ Lincoln School of Engineering \\ Brayford Pool, UK \\ glocatelli@lincoln.ac.uk
}

\author{
Mauro Mancini \\ Politecnico di Milano \\ Department of Management, Economics \& \\ Industrial Engineering, Milano - Italy \\ mauro.mancini@polimi.it
}

DOI 10.5592/otmcj.2012.2.9

Research paper

THE SO CALLED "NUCLEAR RENAISSANCE" IS CREATING A MILLIONAIRE MARKET FOR NEW NUCLEAR REACTORS. Few firms have the capabilities to work in this complex and highly demanding market, whereas many other are investigating the option to enter. Quite surprising the international scientific literature provides information regarding the high-level governmental aspects of nuclear power programs in different countries while the analysis at firm level is almost inexistent. Moreover the usual business models for the manufacturing industry are not suitable since the nuclear market is very peculiar. In particular is unclear how an EPC (Engineering Procurement and Construction) company can enter in it. This paper deals with this question investigating how an EPC firms or general contractor can enter in the nuclear market. The case study methodology has been widely used to understand the time, cost, enabling factors and barriers to enter in the nuclear business in the most important roles: Architect/ Engineering, NSSS supplier, TG supplier, Construction. The results show that there are strong similarities among companies acting as main contractor in the same field; therefore it is possible to generalize a large set of meaningful lessons learned.

\section{INTRODUCTION AND RESEARCH QUESTIONS}

Nowadays the nuclear market is in a really dynamic condition. Even after the Fukushima Daichi accident (which caused different reactions in governmental plans for nuclear energy development) several countries declared their renewed support and conviction in nuclear energy. Among the others
United Kingdom, France, Romania, Slovakia and Slovenia declared their intentions to not change their nuclear policies (Foratom, 2011). One of the most positive demonstrations toward the nuclear power technology has been made by Saudi Arabia, with its intention to build 16 new nuclear reactors over the next 20 years, for a \$300 billion estimated cost (ArabNews, 2011) 
or the event more recent plans of Belarus and Turkey. Even if the market is very attractive the project delivery chain (supplier, general contractors, advisor etc.) is not enough developed to satisfy the markets demand; therefore many firms are expected to enter the nuclear business. The Project Delivery Chain (PDC) is defined as the individuals and organizations involved in the project, with interests that may be positively or negatively affected as a result of project execution. The components may also exert influence over the project and its results (Project Management Institute, 2000). The PDC for a Nuclear Power Plant (NPP) project changes along with the contractual approach used, however the following designations are always present (IAEA, 1988):

> Public authority;

Regulatory body;

Utility;

Main contractor;

Architect-engineer (AE);

- Consultant;

Subcontractor.

This paper deals with EPC (Engineering Procurement and Construction) firms and therefore focuses on the roles of Main Contractors and Architect/Engineer ( $A E)$. Main contractors are the organizations in charge of the execution of complete functional system (packages) of the nuclear power project. They are key stakeholders in the project governance (Ruuska et al., 2011) and their decisions are fundamental for the project success as demonstrated by the recent projects "Olkiluoto 3 " and "Flamanville 3" (Locatelli and Mancini, 2012). The scope of a main contract typically comprises a fairly self-sufficient package with a minimum of external interfaces, in the form of major sections of the plant, systems or services. The main contractors would plan, engineer and commission the contracted portion of the plant according to the specifications and requirements of the utility and with allowance for the interfaces to other contractors, often under a package con- tract with a fixed price and schedule. They are responsible for the management of the project and sometimes the whole program (Locatelli and Mancini, 2010). A main contractor independently manages the subcontracts for his portion of the plant, possibly with a consent right by the utility.

In the Nuclear Business there are mainly three different types of contract (IAEA, 1999):

- Turnkey approach, where a single contractor or a consortium of contractors takes the overall responsibility for the whole works.

> Split-package approach, where the overall responsibility is divided between a relatively small numbers of contractors, each coping with a large section of the works.

- Multi-contract approach, where the owner, or his architect-engineer, assumes overall responsibility for engineering the station, issuing a large number of contracts.

Due to its widespread application the multi-contract approach will be the reference for this work moreover, with the opportune adaptations (mainly it changes the owner and the risk sharing approach), also the other approaches can be traced back to this one. Multicontract approach allows the subdivisions of a NPP project in a set of standard roles and scopes of work. In this type of approach, prime contractors are defined as the company (or the companies) winning a contract for any of the roles defined in Figure 1.
The multi-contract approach showed in Figure 1 divides roles as follows (IAEA, 2004):

- Architect/Engineer (AE): Project management and engineering management support; owner's personnel training; support services to owner on procurement, construction \& commissioning; other related activities. The term AE is generally applied to organizations which specialize in planning, engineering and managing industrial installations and buildings. AE firms can therefore combine a great deal of experience and accumulate expert know-how transferable from one project to another.

- Nuclear Steam Supply System (NSSS) supplier: System \& component design; equipment supply; delivery of raw material specimens for LBB (Leak Before Break) analysis and other services (technical support, licensing and training);

Turbo-Generator (TG) supplier: Equipment supply including design, engineering \& related information; tests; services; training of owner's personnel; and spare parts;

- Construction contractors: Civil/architectural work, piping and cabling work, installation and erection of mechanical and electrical equipment, yard facilities and commission support within their scope of work.

The percentage of the total overnight cost allocated to each role is showed in Table 1.

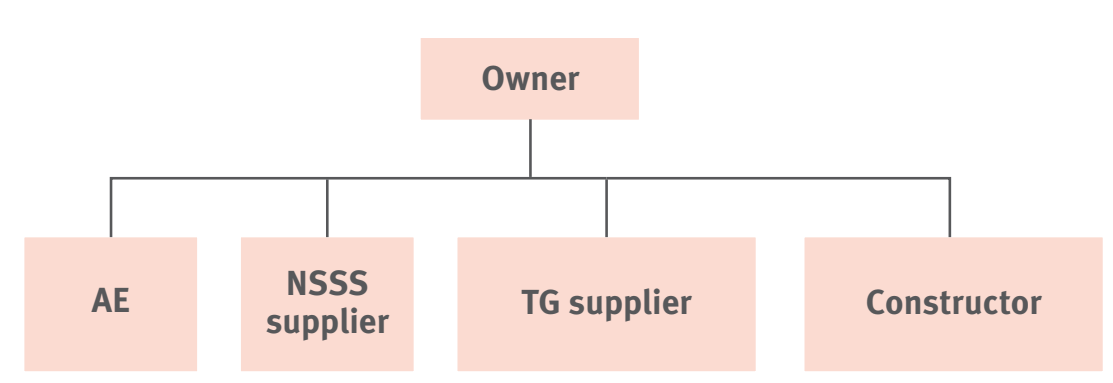

Figure 1 NPP's PDC: multi-contract approach 


\begin{tabular}{|c|c|c|c|c|c|c|c|}
\hline $\begin{array}{c}\text { Reference } \\
\text { plant }\end{array}$ & Country & Technology & $\begin{array}{c}\text { Capacity } \\
(\text { MWe }\end{array}$ & $\begin{array}{c}\text { NSSS supplier } \\
(\%)\end{array}$ & $\begin{array}{c}\text { TG supplier } \\
(\%)\end{array}$ & $\begin{array}{c}\text { Constructor } \\
(\%)\end{array}$ \\
\hline $1(*)$ & France & PWR & 1450 & 29.0 & 26.0 & 17.0 & - \\
\hline 2 & USA & ALWR & 900 & 17.7 & 20.5 & 16.5 & 9.0 \\
\hline 3 & USA & ALWR & 1300 & 18.6 & 21.6 & 17.2 & 9.2 \\
\hline 4 & Germany & PWR & 1380 & 32.0 & 28.7 & 20.9 & 13.8 \\
\hline $5\left(^{(*}\right)$ & Korea & PWR & 1000 & 31.0 & 11.0 & 17.0 & 36.0 \\
\hline
\end{tabular}

Table 1 Shares of NPP's overnight costs, mainly from (NEA, 2000).

$\left.{ }^{*}\right)$ Data based on an average cost calculated for a series of 10 units, which includes a part of the first-of-a-kind costs. (**) Based on Korean plants 10-11, referring to (Sung and Hong, 1999). AE's high share is due to the Technology Transfer costs.

So, even if the market is huge and really attractive is unclear how an Engineering Procurement and Construction (EPC) firm working in other sectors (chemical, Oil\&Gas, etc.) can enter in the nuclear business. In particular the literature shows a huge lack of information concerning modalities and requirements for a General contractor/ EPC company to enter the nuclear business in these aforementioned roles, therefore this gap arises five main research questions:

Q1: Which are the drivers shaping the PDC in a nuclear power plant project?

Q2: Which are the main barriers to enter the nuclear power plant business?

Q3: Which are the enabling factors leading a company to proficiently enter the nuclear power plant business?

Q4: Do exist paths, leading to an entry in nuclear power plant PDC?

Q5: How much time and investment must a company face to enter nuclear power plant business? Are they different along with diverse contractual roles?

In order to answer to these research questions this paper summaries the information provided by several case studies of firms already entered the nuclear business.

\section{Case Study methodology}

Case Study methodology is a scientific method extensively used as a technique to describe and understand not only the players of global nuclear market, but also dynamics leading the companies to enter the market. In order to understand the different scenarios analyzed, it is necessary to present the theory of this research method and how it has been implemented.

\section{Description}

The case studies presented in this paper have been developed according to two main references: (Yin, 2003) and (Flyvbjerg, 2006). According to (Yin, 2003) archival analysis in case study research can be used to answer such questions as what, how often and when. Concerning the validity and reliability of this research, the use of this type of rich public evidence, archival records and documentation, has both advantages and disadvantages. Typically archival and documentary data are completed with other types of evidence such as interviews; hence our sources of evidence may potentially affect the validity of our findings. On the other hand the large potential of this Research Method ${ }^{1}$ in this field, combined with the possibility to rely on multiple sources of evidences, are the main reasons for this methodological choice. This approach results in a simple integration of the information without guiding readers' opinion. Another advantage of the use of this kind of public data is the fact that we

\footnotetext{
1 Traditional prejudices over this Research Method are answered by the considerations of (Flyvbjerg, 2006).
}

can openly discuss the data and our findings in the analysis, by posing the data and the findings for public critique. Such public critique may help to test the correctness of the content of our analysis. The purpose is leading the reader to the outcomes of this work, supported by evidences listed.

\section{Implementation}

The implementation of our case studies follows the "top down approach" presented in Figure 2. The purpose is to understand high-level decisions (typically governmental), and consequently analyze industry's response. Final focus is given to single companies, with details about their path to enter the nuclear business.

With this approach our results and conclusions are useful at two different levels i.e.:

Governmental/policy maker level: since the goal of a policy maker is to maximize the present and future welfare of its citizens, it needs to understand the macro aspects and drivers of a certain business. In order to maximize the outputs from its scarce resources (money, intellectual assets etc...) it needs to assign these resources where they are most effective, so it is necessary to understand which type of firm deserves the greater support and how to provide it.

\footnotetext{
2 These four countries include the two largest Nuclear Consortia: the Areva-MHI, and ToshibaWestinghouse.
} 


\section{Government:}

Nuclear power program

Industry:

National nuclear business

\section{Company:}

Structure, history, partners

\section{Figure 2 Top down approach for Case Studies:}

Firm level: a certain firm, considering its capabilities, assets and core business aims to understand if it would be profitable or not to enter in the nuclear business, and in case of, which benefits would be expected and which gaps have to be overcome.

The parameters used for the country selection were the followings:

- Development of a national nuclear power program

National companies being part of nuclear consortia
- Presence of a national nuclear industry - Availability of scientific articles, regarding the country's nuclear policies Political situation

These parameters led to the choice of four main countries to analyze: Japan, USA, Republic of Korea, and France ${ }^{2}$. These are the first countries in terms of nuclear reactors built inside the country, excluding Russian Federation. According to (Yin, 2003), a Pilot Case Study was prepared before developing the case stud- ies. The United Arab Emirates' (UAE) first NPP project, with the contract's bid won by the Korean Consortium led by KEPCO, has been the topic of this Pilot (see Appendix: Pilot Case Study: UAE's bid for a new NPP project); Figure 3 shows countries and companies analyzed. For the purpose, sources of evidence are integrated through the analysis of three different bibliographic reviews.

The sample considered in this paper includes 21 companies involved in different NPP projects' roles (Figure 3). The countries were these firms are based host a total of 237 NPPs ( $54 \%$ of World's total). The bibliography analyzed (Table 2) comprises scientific papers (organized in three different clusters - Korea \& Japan, France \& USA, UAE contract bid), technical reports (IAEA, NEA, MPR etc.) and archival records (JAIF, 2003) (Scientech, 2010) (Industcards, 2011 a). Along with this documentation, every company was studied through websites, annual reports, news, archival records and conferences reports.

The PDCs are defined elaborating and triangulating information from both archival records (JAIF, Scientech, Industcards) and other sources (company website, annual reports, news, technical reports).

\begin{tabular}{|c|c|c|c|c|}
\hline & Korea & Japan & USA & France \\
\hline Scientific Literature & \multicolumn{2}{|c|}{$\begin{array}{c}\text { (Sung and Hong, 1999) (Choi et al., 2009) (Ahn and } \\
\text { Han, 1998) (Park, 1992) (Valentine and Sovacool, 2010) } \\
\text { (Lesbirel, 1990) (Pickett, 2002) (Park and Chevalier, } \\
\text { 2010) (Berthelémy and Lévêque, 2011) }\end{array}$} & \multicolumn{2}{|c|}{$\begin{array}{c}\text { (Leny Pellissier-Tanon, 1984) (Collingridge, D., 1984 a) } \\
\text { (Collingridge, D., 1984) (Golay, Saragossi and } \\
\text { Willefert, 1977) (Grubler, 2010) (Roche, 2011) } \\
\text { (Boulin and Boiteux, 2000) (David and Rothwell, } \\
\text { 1994) (Plantè, 1998) (Davis, 2011) }\end{array}$} \\
\hline Technical Reports & \multicolumn{4}{|c|}{ NEA, 2000) (IAEA, 2007) (MPR, 2005) (MPR, 2004) (MPR, 2010) (IAEA, 2000) } \\
\hline $\begin{array}{l}\text { NSSS design and } \\
\text { manufacturing }\end{array}$ & KEPCO E\&C & $\begin{array}{l}\text { Hitachi, MHI, } \\
\text { Toshiba }\end{array}$ & $\begin{array}{c}\text { Westinghouse, General } \\
\text { Electric }\end{array}$ & Areva \\
\hline TG supply & Doosan Heavy Industries & $\begin{array}{l}\text { Hitachi, MHI, } \\
\text { Toshiba }\end{array}$ & $\begin{array}{c}\text { Westinghouse, General } \\
\text { Electric }\end{array}$ & Alstom \\
\hline Construction & $\begin{array}{c}\text { Daelim Industrial, } \\
\text { Samsung C\&T, Hyundai } \\
\text { E\&C, Daewoo E\&C, Doosan } \\
\text { E\&C }\end{array}$ & Kajima & $\begin{array}{l}\text { Bechtel, } \\
\text { The Shaw Group }\end{array}$ & Vinci, Bouygues \\
\hline AE & KEPCO E\&C & $\begin{array}{l}\text { Hitachi, MHI, } \\
\text { Toshiba }\end{array}$ & $\begin{array}{l}\text { Bechtel, } \\
\text { The Shaw Group }\end{array}$ & EDF \\
\hline
\end{tabular}

Table 2 The sample: every company has been analyzed through websites, annual reports, news and archival records. 

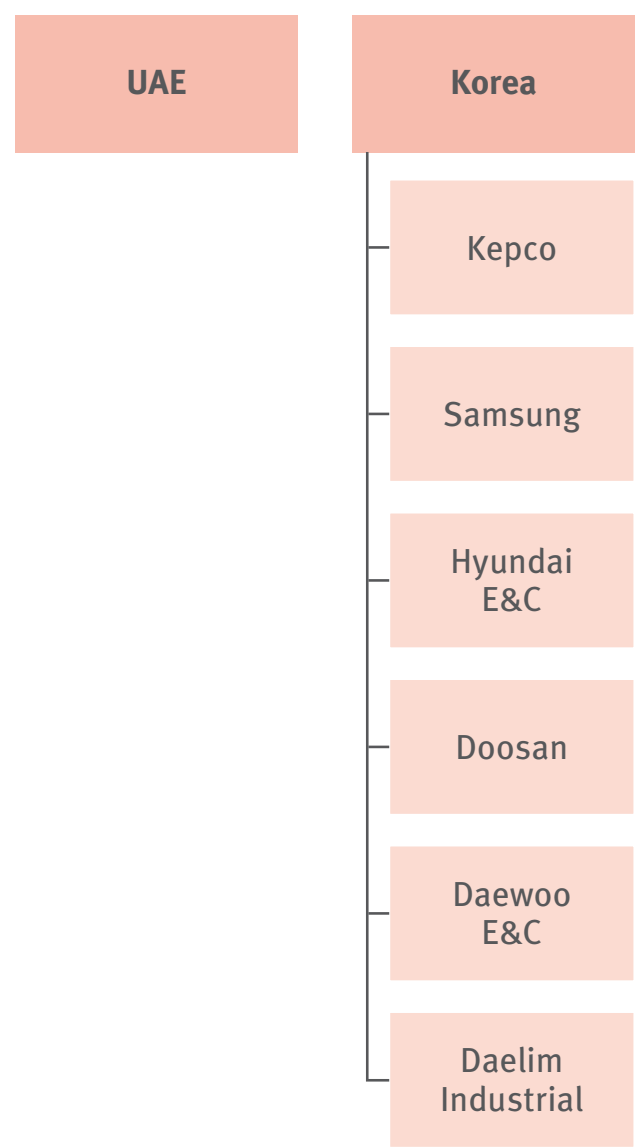
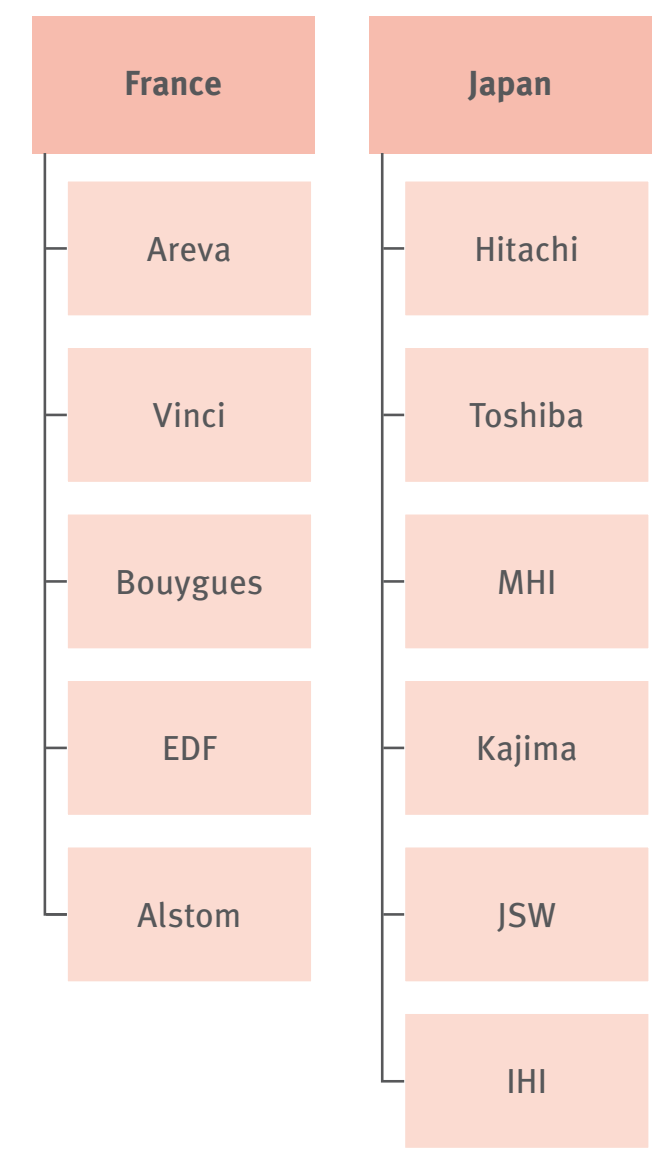

Alstom
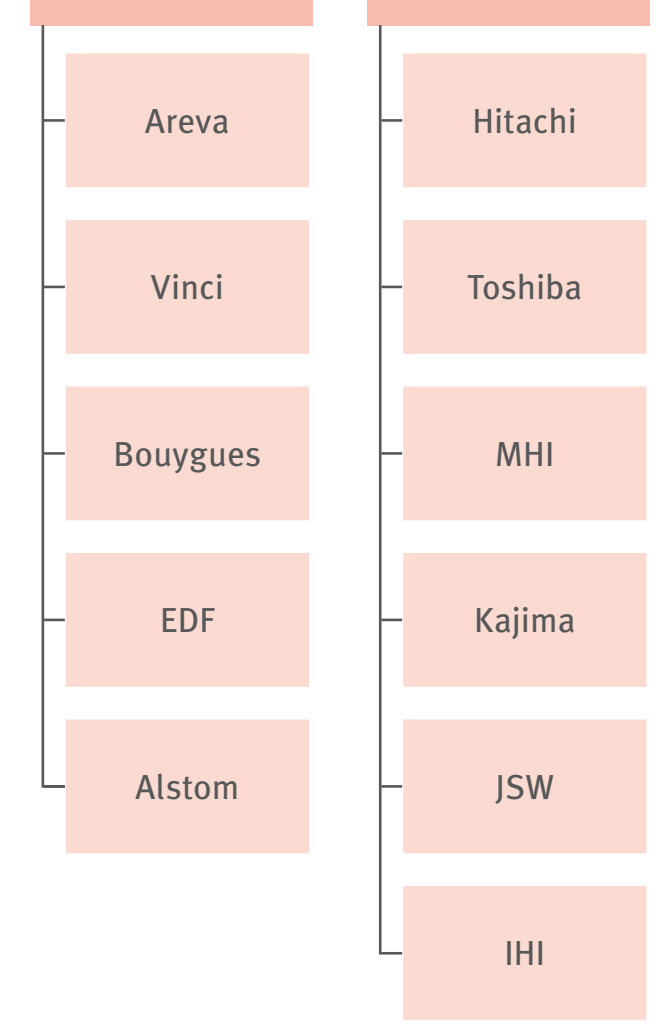

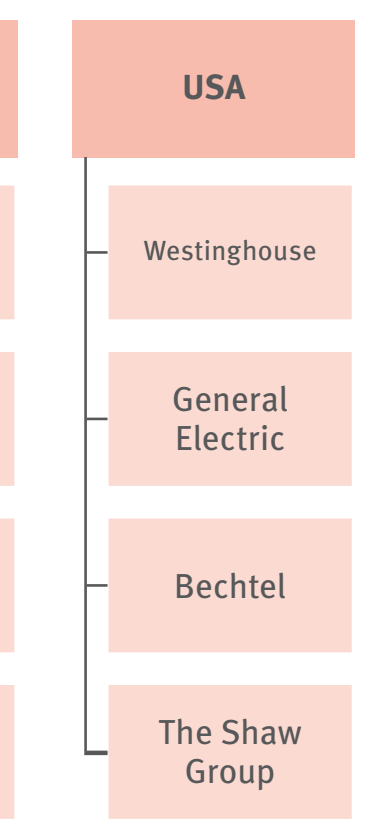

Figure 3 Multiple-Case Study approach chosen: countries and companies analyzed.
The first step involves the subdivision of NPPs, according to the different technologies (PWR and BWR). Then, NPPs are chronologically ordered respect to the date of order of the plant itself (or the construction start, according the available information); these tables have been the basis to develop the cases. Governmental issues (connected with agreements, policies, and laws promoting nuclear power development) were analyzed through scientific papers, which discussed about those topics diffusely. The national industry situation and companies' information were deducted from the other sources of evidence available (Annual Reports, Websites, News, and Technical Reports).

The study of governmental approaches to develop nuclear power programs provided information about the common strategies adopted in the countries interested in developing a national nuclear industry.

In particular the cases highlight the possible choices of:
Having a series of turn-key contracts deployed by foreign suppliers (if domestic industries have not capabilities in the nuclear sector or the government is not interested in developing a national nuclear industry - i.e. UAE).

> Founding joint ventures between local and foreign companies, if local industries are supported by local government (i.e. France, with Framatome), with a Technology Transfer purpose.

Co-operation agreements (i.e. Toshiba and General Electric, Mitsubishi Heavy Industries and Westinghouse) with local participation since first projects. This is the case of an already developed local industry.

In each Case Study, domestic self-reliance was achieved after several project participations. This fact, compared through the analysis of archival records, showed that construction's prime contractual role is to involve local companies since the first national projects i.e. to increase the so called "local content". Usually the TG supply's prime contracts are often controlled and detained by the NSSS suppliers. Technology Transfer processes highlighted the fact that some roles (such as AE and NSSS supplier) require a long time to develop knowledge by the Learning-by-doing process. Companies were then analyzed through the prime contractual role point of view. Main information obtained regarded:

> Companies' history.

Acquisitions, mergers, partnerships.

- Technology Transfer through other companies.

Nuclear business development.

The information was used to create a qualitative matrix, to highlight different paths followed by the companies, and focus on similarities between choices. Figure 4 shows an example of matrix for the Shaw Group: it presents the "nuclear path", with motivations deducted by evi- 


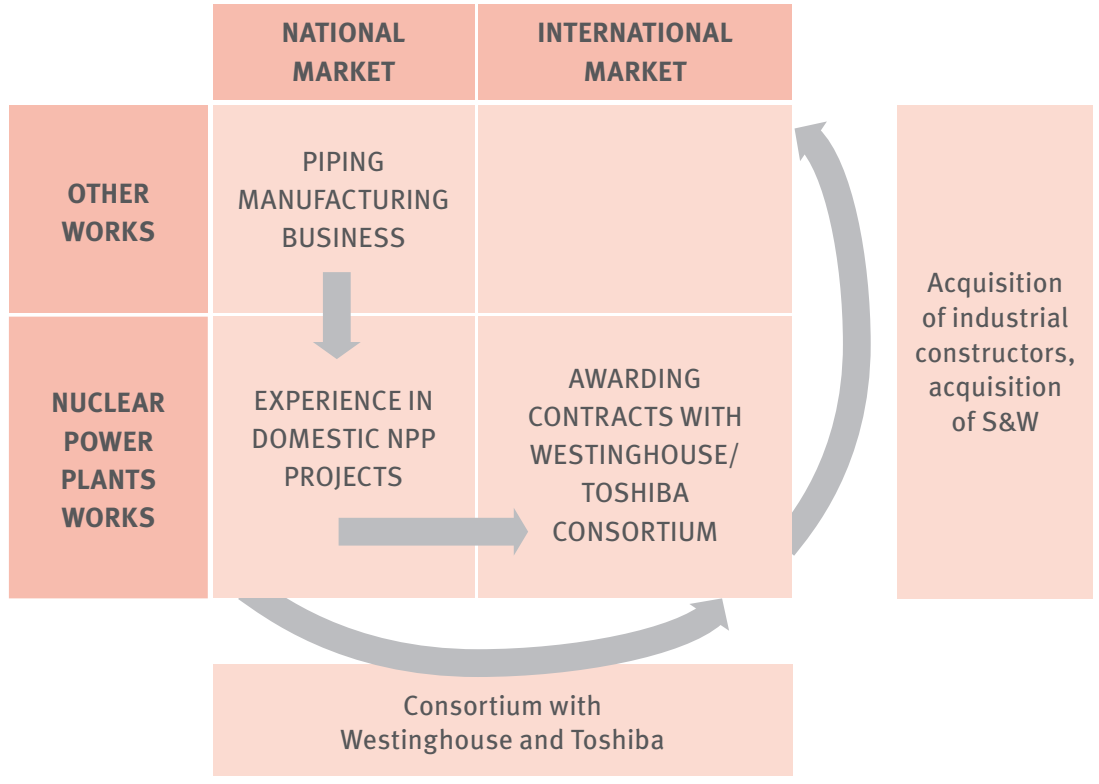

Figure 4 The Shaw Group: nuclear "path"

dences, causing the transitions between quadrants. All the information collected contributed to define these shifts. The matrix model is used for all the companies analyzed. Shifting is represented by an arrow and is tested by the analysis over the company's history. In the side boxes are drawn reasons, events and strategies leading to the shifting. Figure 5 shows the prospect of the sources and the integration process guiding to the Research Answers.

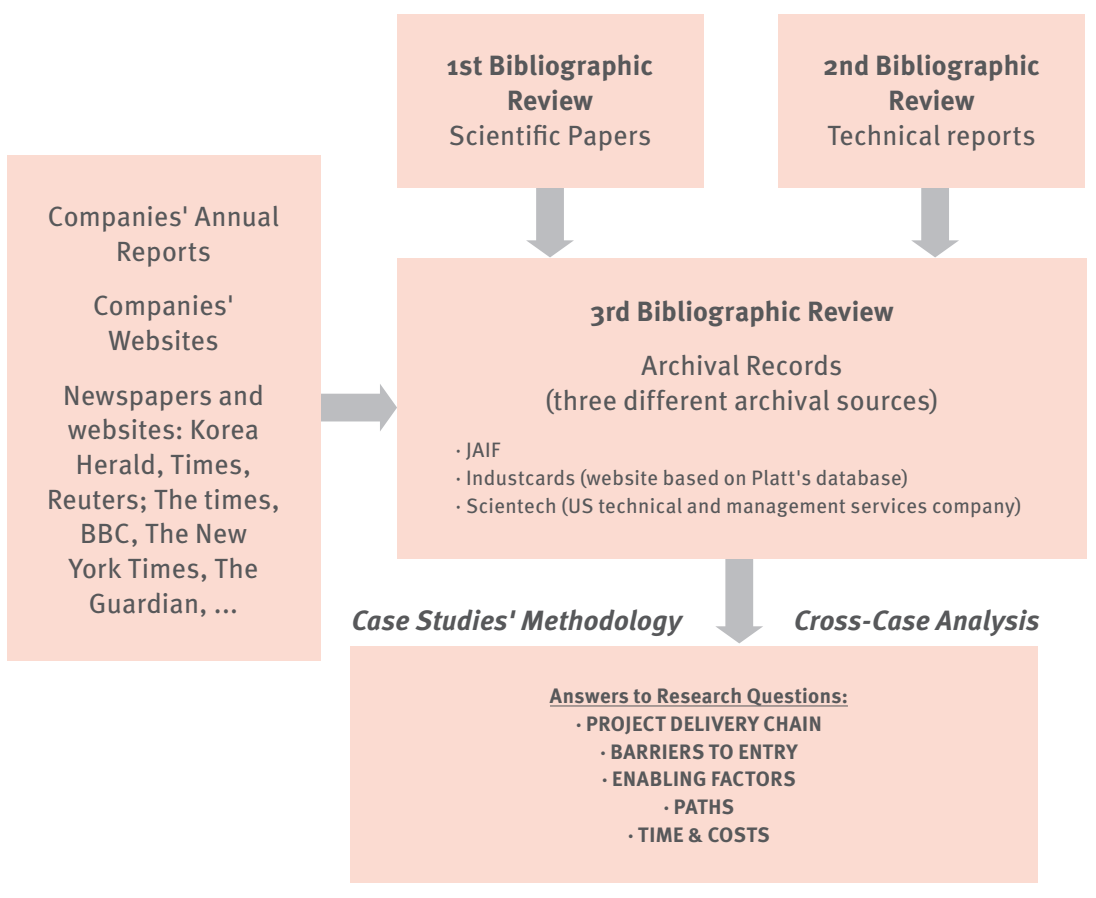

Figure 5 Methodology and sources of evidence for the work: three different bibliographic sources have been reviewed, along with the application of Case Studies' Methodology

\section{Results \\ Barriers and enabling factors \\ Barriers to entry}

The evaluation of the barrier to entry in nuclear market can be deducted from the integration of information contained in scientific papers and cross-case analysis of the case studies.

The most evident barriers to entry in the nuclear market is the government support. Government's support to national companies and the presence of a nuclear power program is a "Condicio sine qua non" to enter the field. Beside the government role, the case studies prove as there are not EPC companies directly entered the international nuclear market as a prime contractor. Each EPC (or major contractor) had past experiences in national NPP projects, before shifting to foreign NPP projects. In presence of a governmental support other barriers are role-dependent, according to the prime contractual role assumed by the company. They are presented in Table 3.

Historically, technological barriers (i.e. the NSSS design capabilities, or the $A E$ ones) were bypassed with a government founding support (to self-develop the capabilities), or partnerships with foreign companies, through a Technology Transfer process. The specific role of NSSS manufacturer presents the largeforgings' supply chain problem. Companies such as Hitachi and Mitsubishi secured a share of Japan Steel Works' stakes, in order to have privileged relations, with one of the few world suppliers of these components. The investment in a manufacturing plant capable to forge such components, according to (MPR, 2010) is unprofitable unless it is fully exploited. As noticed, the construction's prime contract seems to be the most appealing for a national EPC company.

\section{Enabling factors to enter the nuclear market}

Enabling factors are the capabilities that a company needs in order to satisfy the requirement of a prime contractual role. 


\begin{tabular}{|c|c|c|c|c|}
\hline & Role & $\begin{array}{l}\text { Government } \\
\text { support as first } \\
\text { main barrier }\end{array}$ & $\begin{array}{l}\text { "Other" barriers } \\
\text { / Capabilities }\end{array}$ & $\begin{array}{l}\text { Strategy to bypass } \\
\text { "other" entry } \\
\text { barriers }\end{array}$ \\
\hline \multirow[b]{2}{*}{$\begin{array}{l}\text { NSSS } \\
\text { Supplier }\end{array}$} & Design & Yes & Core Technology & Technology Transfer \\
\hline & Manufacturing & Yes & $\begin{array}{l}\text { Large Forgings' } \\
\text { Supply }\end{array}$ & $\begin{array}{l}\text { Great investment } \\
\text { or privileged } \\
\text { relationship with } \\
\text { supplier }\end{array}$ \\
\hline & $\mathrm{AE}$ & Yes & $\begin{array}{c}\text { Basic and } \\
\text { Detailed Design }\end{array}$ & Technology Transfer \\
\hline \multicolumn{2}{|c|}{ TG Supplier } & Yes & $\begin{array}{l}\text { NSSS suppliers' } \\
\text { "power” }\end{array}$ & Technology Transfer \\
\hline \multicolumn{2}{|c|}{ Constructor } & Yes & $\begin{array}{c}\text { Dimension and } \\
\text { capabilities }\end{array}$ & Technology Transfer \\
\hline
\end{tabular}

Table 3 Barriers according to the prime contractual role covered by a company
This can be summarized in three main categories:

Workforce

$\checkmark$ Qualifications

Technological know-how

Partial information about the enabling factors' issue has been reported by (IAEA, 2007) (MPR, 2004) (MPR, 2005) (MPR, 2010). Several matches between data were found during the development of Case Studies (Energybiz, 2007) (Roche, 2011). The enabling factors are strictly connected with the technical role assumed in the project's context. A summary of the results is reported in Table 4.

One of the most important enabling factors to enter the nuclear business is the certification. American Society of Mechanical Engineers - ASME - is the

\begin{tabular}{|c|c|c|c|c|c|}
\hline $\begin{array}{l}\text { Technical role } \\
\text { in the project }\end{array}$ & & $\begin{array}{l}\text { "Other" barriers / } \\
\text { Capabilities }\end{array}$ & Basic design & Detailed design & Total \\
\hline \multirow{4}{*}{$\mathrm{AE}$} & $\begin{array}{l}\text { Level of effort } \\
\text { (man-hours) }\end{array}$ & - & $300,000-500,000$ & $2,500,000$ & $3,000,000$ \\
\hline & Staff & $\begin{array}{l}\text { 20-30 experienced } \\
\text { engineers and } \\
\text { technicians }\end{array}$ & $200-300$ & $\begin{array}{l}\text { Depending on NSSS, } \\
\text { TG, BOP manufacturer } \\
\text { design and site } \\
\text { conditions }\end{array}$ & - \\
\hline & Period (years) & Up to 2.5 & $0.5-1$ & $3-5$ & $3-5$ \\
\hline & Cost & - & - & - & $\begin{array}{l}10 \% \text { total NPP cost (not } \\
\text { first of a kind) }\end{array}$ \\
\hline $\begin{array}{l}\text { Technical role } \\
\text { in the project }\end{array}$ & & Components' design & Qualifications & \multicolumn{2}{|c|}{ Other enabling factors } \\
\hline \multirow{2}{*}{$\begin{array}{l}\text { NSSS and TG } \\
\text { Manufacturing }\end{array}$} & $\begin{array}{l}\text { Level of effort } \\
\quad \text { (MH) }\end{array}$ & $20,000,000$ & \multirow{2}{*}{$\begin{array}{l}\text { ASME Certifications, } \\
\text { depending on the } \\
\text { particular component }\end{array}$} & \multirow{2}{*}{\multicolumn{2}{|c|}{$\begin{array}{l}\text { Large forgings require sufficient manufacturing } \\
\text { capabilities (for the Reactor Pressure Vessel) }\end{array}$}} \\
\hline & Number of items & 30,000 & & & \\
\hline $\begin{array}{l}\text { Technical role } \\
\text { in the project }\end{array}$ & & $\begin{array}{l}\text { Preparation of site } \\
\text { infrastructure }\end{array}$ & $\begin{array}{l}\text { Erection of plant } \\
\text { buildings and } \\
\text { structures }\end{array}$ & $\begin{array}{l}\text { Plant equipment, } \\
\text { components and } \\
\text { systems erection and } \\
\text { installation }\end{array}$ & Other enabling factors \\
\hline Construction & Staff & $\begin{array}{c}50 \text { to } 150 \text { craftsmen } \\
10-20 \text { professional } \\
\text { managers }\end{array}$ & $\begin{array}{c}1,000 \text { to } 1,200 \text { at the } \\
\text { peak }\end{array}$ & $\begin{array}{l}1,300 \text { people } \\
\text { (technicians and } \\
\text { craftsmen) }\end{array}$ & $\begin{array}{l}\text { Advanced construction } \\
\text { technologies and } \\
\text { ASME Certifications }\end{array}$ \\
\hline
\end{tabular}




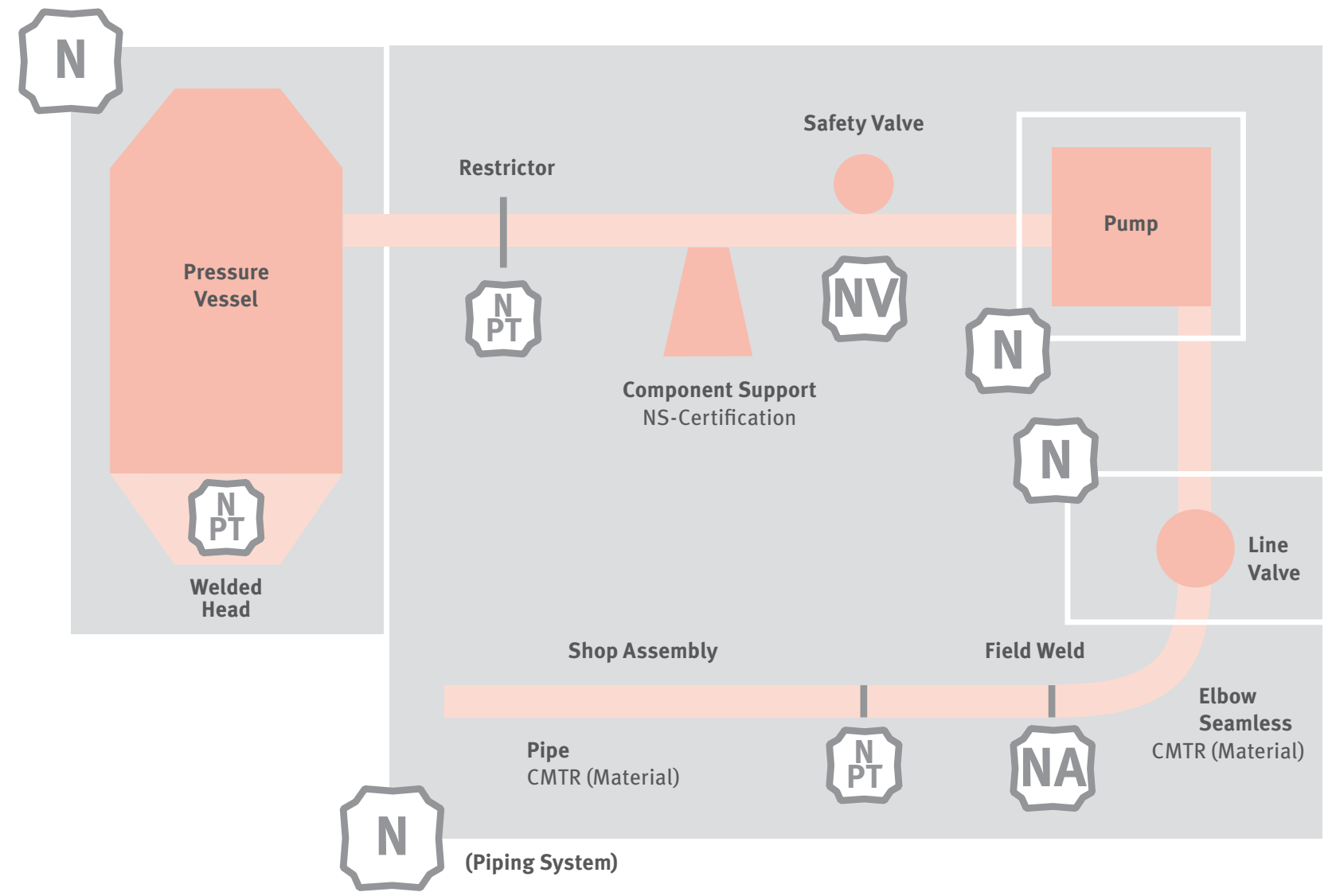

Figure 6 Example of ASME's Stamps required, adapted from (ONE/TUV/BV, 2009).

most recognized at a global level, however it is not the only one, e.g. French companies require the RCC-M Certifications (that are a development of ASME certification). ASME's NA (Nuclear In- stallation and Shop Assembly) and NPT (Nuclear Partials) stamps or equivalent are required to operate in the NPP's construction business. These stamps certificate the company's capabilities in

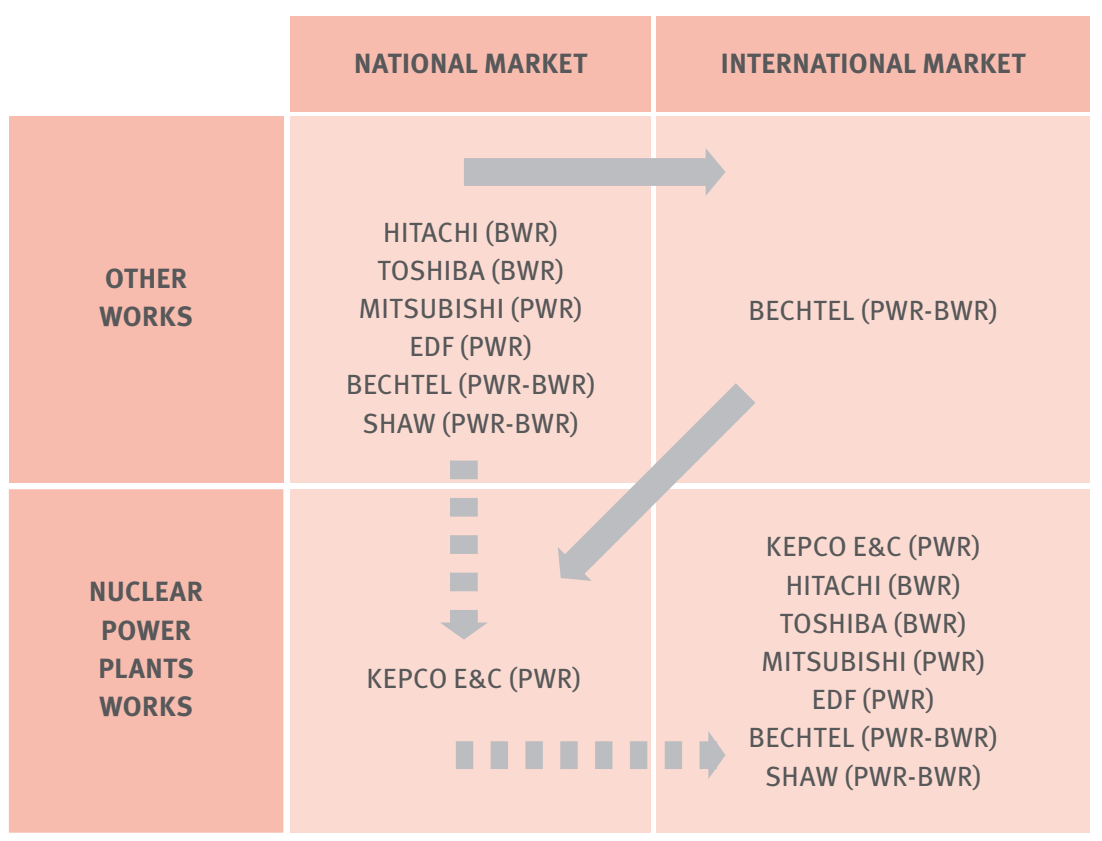

terms of assembly of components and welded parts of nuclear components (ASME, 2011 a) (ASME, 2011 b). Figure 6 shows an extremely synthetic idea of Stamps required during a NPP projects: the scheme presents the main elements in a nuclear island requiring the ASME stamp certification. The synthetic scheme puts focus on the different stamps required. Parts of ASME Stamps are dedicated to the manufacturing process, but there are Stamps coping with the welding process, the assembly or the component supports. Qualifications involve nearly all the companies participating in a NPP project.

Figure 7 Typical pattern for AE's prime contractors: almost all companies follow the "dotted" path: from national generic market to national nuclear market. Bechtel is the only company following the "continuous" pattern. 


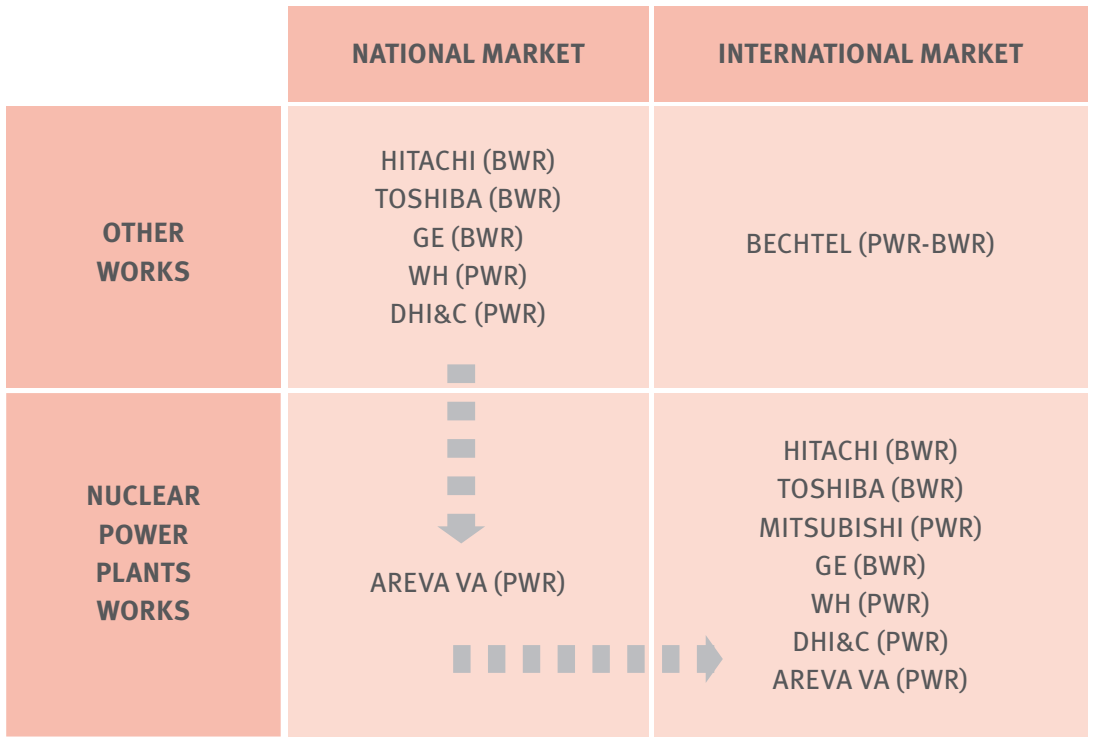

Figure 8 Typical pattern for NSSS supply's prime contractors: companies follow the green path. Areva started directly in the national nuclear market: the company was born through a merger of companies already operating in nuclear market.

(Voutsinos, 2009) reports information regarding ASME Qualifications in NPP projects.

Another critical factor is the Technological Know-How. Technological Know-How in the construction of new NPPs involves the management of advanced techniques focused on shortening the project's schedule. These techniques are mainly (Hitachi, 2008 a) (Hitachi-GE, 2010 b) (Hitachi-GE, 2010 a) (Toshiba America Nuclear Energy, 2010):

> Modularization;

Open-Top Construction;

Very-Heavy Lift cranes (VHL);

$>$ Pipe bending machines;

- Automatic welding machines;

- Automatic rebar assembly machines (for ABWRs).

\section{General paths leading to a nuclear market entry}

The Case Study methodology, along with the matrix approach, shows similarities among companies. Similarities can be found between countries beginning a nuclear program through a Technology Transfer's process. A global picture of paths followed by the World's major players has been generated by applying the matrix described in par. 2.2 (i.e. Figure 4) and comparing different companies operating in same contractual roles. In the next sections Figure 7, Figure 8 and Figure 9 show the results of this analysis.

\section{Architect/Engineering}

Architect/Engineering companies deal with Technology Transfer processes. Large part of these companies shifted from national businesses to international NPP projects partnership with NPP built inside the country (Figure 7). A remarkable example is KEPCO E\&C that has been founded to achieve core technology capabilities and started from the nuclear field (KEPCO E\&C, 2011). The only exception, Bechtel (Bechtel, 2011), reflects the business' orientation of the company itself. Bechtel could be described as a construction-oriented company (more than AE). In facts Bechtel's path matches with results of the Construction business' matrix ${ }^{3}$.

\footnotetext{
3 This fact is due to the impossibility to split roles for a company operating in both $A / E$ 's and Construction's fields.
}

\section{NSSS supplier and TG supplier}

Each company analyzed shifted from national market to national nuclear business then to international NPP projects (Figure 8).

This prime contractor's role presents Technology Transfer's issues, similarly to the AE role. The know-how was achieved through partnerships (with governmental support, i.e. (Barrè, 2008) (WNA, 2011 a)) and with synergic efforts in R\&D since the first years after the WWII (i.e. (WNA, 2011 a), (WNA, 2011 b)). The only exception is Areva since it started its path into nuclear business directly. Its foundation was committed to develop nuclear technology with the merger of Framatome (now AREVA NP), Cogema (now AREVA NC) and Technicatome (now AREVA TA) in 2001 (AREVA, 2009). NSSS suppliers are also often TG suppliers for a NPP project. In France, where the government has a stronger decisional power than any other analyzed country (since its shareholdings in many national nuclear-related companies) Alstom is the privileged TG supplier (Alstom, 2011). This represents one of the few exceptions evidenced.

\section{Constructor}

The largest part of analyzed companies entered national nuclear business starting from international businesses (Figure 9). The exception is The Shaw Group. Before the acquisition of Stone \& Webster (S\&W, 2011) (The New York Times, 2000), its core business was mainly piping manufacturing (Shaw, 2011). The acquisition of an historic large-engineering company such as Stone \& Webster led to a direct entry into NPP projects' business, with the "instantaneous" acquisition of the capabilities. The Shaw Group shifted directly from national conventional market to national nuclear business. The Stone \& Webster's acquisition is the motivation for Shaw's “instantaneous” knowledge's acquisition. Stone \& Webster was a large-engineering company already operating in nuclear business. Companies, after the 


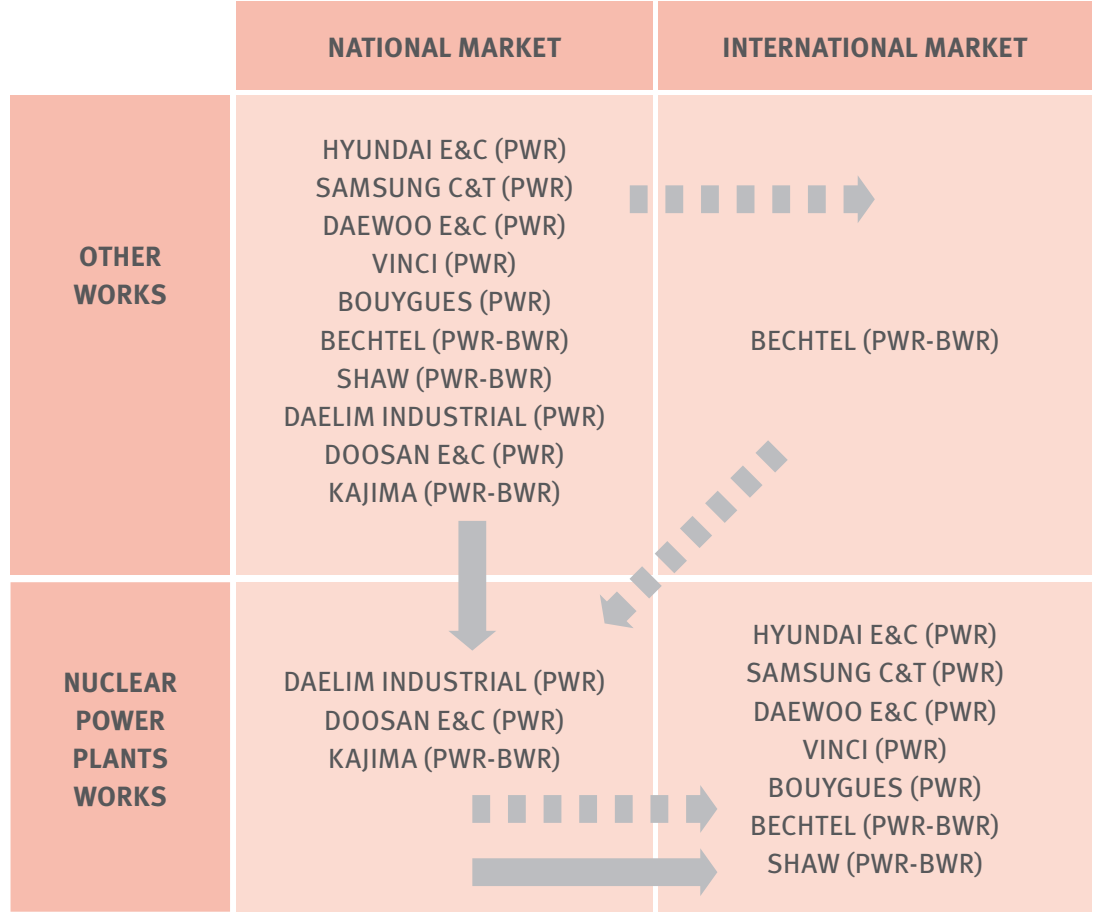

Figure 9 Typical pattern followed by Constructors' prime contractors: almost all companies follow the "dotted" path. Only The Shaw Group shifted directly from national conventional market to national nuclear business. The Stone \& Webster's acquisition is the motivation for Shaw's "instantaneous" acquisition of knowledge. S\&W was a large-engineering company already operating in nuclear business. acquisition of an engineering-oriented company, followed a path more compatible with the AE's ones.

\section{Learning process and time to enter the nuclear business}

Time and costs required to enter the nuclear business depend mainly on the role covered into the PDC. Most of NPP projects in a country are built in parallel in order to benefit from early projects due to the learning curve process. So a year-based learning process estimate is not particularly indicative: for our purposes time estimation will be defined in terms of number of projects participations. This approach has been used for Japanese, Korean, French and US NPPs see from Table 5 to Table 9.

\section{Architect/Engineering}

Time-to-market strongly relies on Technology Transfer and learning-by-doing processes. This evidence is reflected in KEPCO E\&C and other companies such as EDF or Japanese ones (MHI, Hitachi, Toshiba) (Barrè, 2008) (WNA, 2011 a)

\begin{tabular}{|c|c|c|c|c|c|c|c|}
\hline & Plant & $\begin{array}{l}\text { Type } \\
\text { (MWe) }\end{array}$ & $\mathbf{A E}$ & NSSS Supplier & TG Supplier & Constructor & $\begin{array}{c}\text { Construction } \\
\text { period }\end{array}$ \\
\hline Plant 1 & Kori 1 & PWR (587) & GILBERT & WH & GEC & $\begin{array}{c}\text { G WIMPEY } \\
(\text { WH), DONG AH }\end{array}$ & $1970-1978$ \\
\hline Plant 2 & Kori 2 & PWR (650) & GILBERT & WH & GEC & WH/GEC & $1976-1983$ \\
\hline Plant 3 & Wolsong 1 & PHWR (679) & $\mathrm{AECL}$ & $\mathrm{AECL}$ & HP & $\mathrm{AECL}$ & $1975-1983$ \\
\hline Plant 4 & Kori 3 & PWR (950) & BECHTEL & WH & GE & HDEC & $1978-1986$ \\
\hline Plant 5 & Kori 4 & PWR (950) & BECHTEL & WH & WH & HDEC & $1978-1986$ \\
\hline Plant 6 & Yonggwang 1 & PWR (950) & BECHTEL & WH & WH & HDEC & $1979-1987$ \\
\hline Plant 7 & Yonggwang 2 & PWR (950) & BECHTEL & WH & WH & HDEC & $1979-1987$ \\
\hline Plant 8 & Ulchin 1 & PWR (950) & AREVA5 & AREVA & ALSTOM & $\begin{array}{l}\text { DONG AH, } \\
\text { DHI\&C }\end{array}$ & $1981-1990$ \\
\hline Plant 9 & Ulchin 2 & PWR (950) & AREVA & AREVA & ALSTOM & $\begin{array}{l}\text { DONG AH, } \\
\text { DHI\&C }\end{array}$ & $1981-1990$ \\
\hline Plant 10 & Yonggwang 3 & PWR (1000) & KOPEC/S\&L & DHI\&C/WH & DHI\&C /GE & HDEC & $1987-1996$ \\
\hline Plant 11 & Yonggwang 4 & PWR (1000) & KOPEC/S\&L & DHI\&C /WH & DHI\&C /GE & HDEC & $1987-1996$ \\
\hline Plant 12 & Ulchin 3 & OPR (1000) & KOPEC & DHI\&C & DHI\&C & $\begin{array}{c}\text { DONG AH, } \\
\text { DHI\&C }\end{array}$ & 1991-1999 \\
\hline
\end{tabular}

Table 5 First nuclear power plants built in Korea. Integrated from (Park, 1992) (Sung and Hong, 1999) (JAIF, 2003)

(Scientech, 2010) (Industcards, 2011 b) 


\begin{tabular}{|c|c|c|c|c|c|c|c|}
\hline Plant & $\begin{array}{c}\text { Net capacity } \\
\text { (MWe) }\end{array}$ & Date of order & Owner/ Utility & AE & NSSS supplier & TG supplier & Constructor \\
\hline Mihama-1 & 320 & 1967 & Kansai EPCO & $\begin{array}{c}\text { Kansai EPCO/ } \\
\text { Gilbert }\end{array}$ & WH/MHI & $\mathrm{MH}$ & $\begin{array}{c}\text { Maeda/Kum/ } \\
\text { Obay }\end{array}$ \\
\hline Mihama-2 & 470 & 1968 & Kansai EPCO & $\begin{array}{c}\text { Kansai EPCO/ } \\
\mathrm{MHI}\end{array}$ & $\mathrm{WH} / \mathrm{MHI}$ & $\mathrm{MHI}$ & $\begin{array}{c}\text { Maeda/Kum/ } \\
\text { Obay }\end{array}$ \\
\hline Genkai-1 & 529 & 1969 & Kyushu EPCO & $\mathrm{MHI}$ & $\mathrm{MHI}$ & $\mathrm{MHI}$ & Obay/various \\
\hline Takahama-1 & 780 & 1970 & Kansai EPCO & $\begin{array}{c}\text { Kansai EPCO/ } \\
\text { Gilbert }\end{array}$ & $\mathrm{WH} / \mathrm{MHI}$ & $\mathrm{MHI}$ & $\begin{array}{c}\text { Maeda/Haz/ } \\
\text { Taisei }\end{array}$ \\
\hline Takahama-2 & 780 & 1970 & Kansai EPCO & $\begin{array}{c}\text { Kansai EPCO/ } \\
\text { MHI }\end{array}$ & $\mathrm{MHI}$ & $\mathrm{MHI}$ & $\begin{array}{c}\text { Maeda/Haz/ } \\
\text { Taisei }\end{array}$ \\
\hline Mihama-3 & 780 & 1972 & Kansai EPCO & $\mathrm{MHI}$ & $\mathrm{MHI}$ & $\mathrm{MHI}$ & $\begin{array}{l}\text { Hazama/ } \\
\text { Takenaka }\end{array}$ \\
\hline
\end{tabular}

Table 6 First PWR nuclear power plants built in Japan. Elaborated from (JAIF, 2003) (Scientech, 2010) (WNA, 2011 a) (Industcards, $2011 \mathrm{c}$ )

\begin{tabular}{|c|c|c|c|c|c|c|c|}
\hline Reactor & $\begin{array}{l}\text { Net capacity } \\
\text { (MWe) }\end{array}$ & Date of order & $\begin{array}{l}\text { Owner/ } \\
\text { Utility }\end{array}$ & AE & NSSS supplier & TG supplier & Constructor \\
\hline Tsuruga-1 & 341 & 1965 & JAPC & EBASCO & $\begin{array}{c}\text { B\&W/Hitachi/ } \\
\text { GE }\end{array}$ & GE/Toshiba & $\begin{array}{c}\text { Takenaka/ } \\
\text { Kumagai }\end{array}$ \\
\hline Fukushima I-1 & 439 & 1966 & TEPCO & EBASCO & $\begin{array}{l}\text { GE/Toshiba } \\
\text { (IHI) }\end{array}$ & GE & Kajima/various \\
\hline Shimane-1 & 439 & 1966 & Chugoku EPCO & Hitachi & Hitachi & Hitachi & $\begin{array}{c}\text { Kajima/Taisei/ } \\
\text { Goyou/Maeda/ } \\
\text { Kumagai }\end{array}$ \\
\hline Fukushima I-2 & 760 & 1968 & TEPCO & EBASCO & $\begin{array}{l}\text { GE/Toshiba } \\
\quad(\mathrm{IHI})\end{array}$ & GE/Toshiba & $\begin{array}{l}\text { Kajima / } \\
\text { Kumagaiz }\end{array}$ \\
\hline Fukushima I-3 & 760 & 1970 & TEPCO & Toshiba & Toshiba/IHI & Toshiba & $\begin{array}{c}\text { Kumagai/ } \\
\text { Kajima }\end{array}$ \\
\hline Hamaoka-1 & 515 & 1971 & Chubu EPCO & Toshiba & Toshiba (IHI) & Hitachi & (various) \\
\hline Tokai-2 & 1060 & 1971 & JAPC & EBASCO & GE & GE & $\begin{array}{l}\text { Shimizu/ } \\
\text { Kajima }\end{array}$ \\
\hline Fukushima I-4 & 760 & 1972 & TEPCO & Hitachi & $\begin{array}{c}\text { Toshiba/IHI/ } \\
\text { Hitachi }\end{array}$ & Toshiba & Kajima/various \\
\hline
\end{tabular}

Table 7 First BWR nuclear power plants built in Japan. Elaborated from (JAIF, 2003) (Scientech, 2010) (WNA, 2011 a) (Industcards, 2011 c)

(Sung and Hong, 1999) (Roche, 2011). KEPCO E\&C started achieving capabilities from the detailed design along with Bechtel during the project to build the $4^{\text {th }}, 5^{\text {th }}, 8^{\text {th }}$ and $9^{\text {th }}$ Korean plants. Basic design was then obtained along with $\mathrm{S} \& \mathrm{~L}$ through Technology Transfer in plants $10 \& 11$. So the total experience to achieve self-reliance went from plant 4 to plant 11 (Table 5) (Sung and Hong, 1999).
The situation is different in the French scenario, since the French Nuclear Power Program was based on the multiple-package contract approach. EDF achieved detailed engineering with 


\begin{tabular}{|c|c|c|c|c|c|c|c|}
\hline \multicolumn{1}{|c|}{ Plant } & $\begin{array}{c}\text { Net capacity } \\
\text { (MWe) }\end{array}$ & Date of order & $\begin{array}{c}\text { Owner/ } \\
\text { Utility }\end{array}$ & AE & NSSS supplier & TG supplier & Constructor \\
\hline Ginna & 581 & 1965 & RG\&EC & GILBERT & WH & WH & BECHTEL \\
\hline Indian Point 2 & 1025 & 1965 & ENTERGY N & UE\&C & WH & WH & UE\&C \\
\hline $\begin{array}{c}\text { Turkey Point } 3 \\
\text { Diablo Canyon }\end{array}$ & 693 & 1965 & FPL & BECHTEL & WH & WH & BECHTEL \\
\hline \begin{tabular}{c|c}
1 \\
Fort Calhoun
\end{tabular} & 1122 & 1966 & PG\&E & $\begin{array}{c}\text { PG\&EC/ } \\
\text { BECHTEL }\end{array}$ & WH & WH & PG\&E/BECHTEL \\
\hline $\begin{array}{c}\text { H.B. Robinson } \\
2\end{array}$ & 710 & 1966 & OPPD & G\&H & WH & GE & G\&H/D\&R \\
\hline
\end{tabular}

Table 8 First PWR (Pressurized water reactor) nuclear power plants built in USA. Elaborated from (JAIF, 2003) (Scientech, 2010) (WNA, 2011 a) (Industcards, 2011 d) (Industcards, 2011 e) (Industcards, 2011 f) (Industcards, 2011 g) (Industcards, 2011 h) (Industcards, 2011 i) (Industcards, 2011 l) (Industcards, 2011 m) (Industcards, 2011 n) (Industcards, 2011 0) (Industcards, 2011 p)

\begin{tabular}{|c|c|c|c|c|c|c|c|}
\hline Plant & $\begin{array}{c}\text { Net capacity } \\
\text { (MWe) }\end{array}$ & Date of order & $\begin{array}{c}\text { Owner/ } \\
\text { Utility }\end{array}$ & AE & NSSS supplier & TG supplier & Constructor \\
\hline $\begin{array}{c}\text { Nine Mile } \\
\text { Point 1 }\end{array}$ & 621 & 1963 & CNG & NIMO & GE & GE & SHAW/NIMO \\
\hline Oyster Creek 1 & 615 & 1963 & AMERGEN & B\&R & GE & GE & B\&R \\
\hline Dresden 2 & 867 & 1965 & EXELON N & S\&L & GE & GE & UE\&C \\
\hline Pilgrim 1 & 685 & 1965 & ENTERGY N & BECHTEL & GE & GE & BECHTEL \\
\hline Browns Ferry 1 & 1040 & 1966 & TVA & TVA & GE & GE & TVA \\
\hline
\end{tabular}

Table 9 First BWR (Boiling water reactor) nuclear power plants built in USA. Elaborated from (JAIF, 2003) (Scientech, 2010) (WNA, 2011 a) (Industcards, 2011 d) (Industcards, 2011 e) (Industcards, 2011 f) (Industcards, 2011 g) (Industcards, 2011 h) (Industcards, 2011 i) (Industcards, 2011 l) (Industcards, 2011 m) (Industcards, 2011 n) (Industcards, 2011 o) (Industcards, 2011 p)

the help of subcontractors (Roche, 2011). Regarding Japanese companies (like Hitachi, Toshiba and Mitsubishi) there is evidence of a relatively shorter time-tomarket for the AE role, since relationship with foreign suppliers were limited to one or two plants, usually FOAKs of this size series (Table 6 and Table 7).

Considering the US Case Study, The Shaw Group is an important example of instantaneous entry. The acquisition of S\&W (S\&W, 2011) (The New York Times, 2000), previously experienced on such projects in USA (Table 8 and Table 9), enabled Shaw to enter the market. The costs to become an $\mathrm{AE}$ are difficult to estimate, since Technology Transfer and learning by doing techniques are often involved. The lack of information about Technology
Transfer costs and license costs does not permit further analysis.

\section{NSSS supplier}

The topic is similar to the AE one but the discussion must be detailed in terms of NSSS design and NSSS manufacturing. Korean Case Study is the main source of information about Technology Transfer process for NSSS design (plant $4 \mathrm{KAERI}$ started developing NSSS design capabilities through Technology Transfer and learning-by-doing processes). According to Table 5, self-reliance was achieved at the time of Plants $10 \& 11$, through a strong agreement with $\mathrm{CE}$ (now WH) that brought KAERI to a 95\% (Sung and Hong, 1999) share of NSSS design in 1995. Information on NSSS manufacturing shows that a similar path was followed by local manufacturers (Hanjung, later acquired by Doosan Group); an $87 \%$ share of local participation in NSSS manufacturing were achieved in 1995. DHI\&C completed Changwon Plant Site in 1982, with a 13,000 tons press (WNA, 2011 c). In the UAE bid Westinghouse still supplies a $5-7 \%$ of components (nuclear design code, RCP, MMIS) for which Korean companies are not self-reliant. Korean government had an important role in this process, signing a bilateral agreement with the U.S.A. and supporting local manufacturing industries with several ad hoc policies (Sung and Hong, 1999).

Focusing on France the NSSS design and manufacturing roles were both undertaken by Framatome (now Areva), with the specialized knowledge acquired through a licensing process. Westing- 


\begin{tabular}{|c|c|c|c|c|c|c|c|}
\hline Buyer & What & Market & Description & Cost & Year & Reference & $\begin{array}{l}\text { Today (2010- } \\
\text { GDP deflator) }\end{array}$ \\
\hline Shaw & S\&W & $\mathrm{AE}$ & $\begin{array}{c}\text { Shaw acquires } \\
\text { S\&W }\end{array}$ & $\$ 600 m$ & 2000 & $\begin{array}{l}\text { (The New York } \\
\text { Times, 2000) }\end{array}$ & $\$ 749 m$ \\
\hline Toshiba & WH & NSSS supplier & $\begin{array}{c}\text { Toshiba } \\
\text { acquires WH }\end{array}$ & $\$ 4.2 \mathrm{bn}$ & 2006 & $\begin{array}{c}\text { (Financial } \\
\text { Times, 2006) } \\
\text { (Toshiba, 2006) }\end{array}$ & $\$ 4.5 b n$ \\
\hline Areva & $\begin{array}{c}\text { Areva-Siemens } \\
\text { JV }\end{array}$ & NSSS supplier & $\begin{array}{c}\text { Siemens sells } \\
34 \% \text { of its JV } \\
\text { with Areva }\end{array}$ & $\begin{array}{l}€_{1.62 b n} \\
(\$ 2.33 \mathrm{bn})\end{array}$ & 2011 & $\begin{array}{l}\text { (Nuclear Power } \\
\text { Daily, 2011) }\end{array}$ & $\$ 2.33 b n$ \\
\hline JSW & Pressa & $\begin{array}{c}\text { NSSS } \\
\text { manufacturing }\end{array}$ & $\begin{array}{l}\text { Hydraulic } \\
\text { presse }\end{array}$ & $\$ 2$ bn & 2011 & (MPR, 2010) & $\$ 2$ bn \\
\hline Doosan & Hanjung & $\begin{array}{c}\text { NSSS } \\
\text { manufacturing }\end{array}$ & $\begin{array}{l}\text { Doosan } \\
\text { acquires } \\
\text { Hanjung }\end{array}$ & $\$ 257.97 \mathrm{~m}$ & 2000 & $\begin{array}{l}\text { (Highbeam, } \\
\text { 2000) }\end{array}$ & $\$ 322 \mathrm{~m}$ \\
\hline Bouygues & Alstom & TG supplier & $\begin{array}{l}\text { Bouygues } \\
\text { acquires } 21.3 \% \\
\text { of Alstom's } \\
\text { stakes from } \\
\text { the French } \\
\text { Government }\end{array}$ & $\begin{array}{l}€ 1.26 \mathrm{bn} \\
(\$ 1.66 \mathrm{bn})\end{array}$ & 2006 & $\begin{array}{l}\text { (The Guardian, } \\
\text { 2006) }\end{array}$ & $\$ 1.78 b n$ \\
\hline DHI\&C & Skoda Power & TG supplier & $\begin{array}{l}\text { DHI\&C acquires } \\
\text { Skoda Power }\end{array}$ & $\$ 633 m$ & 2009 & $\begin{array}{c}\text { (Financial } \\
\text { Times, 2009) }\end{array}$ & $\$ 639 m$ \\
\hline
\end{tabular}

Table 10 Strategies followed by companies to enter the nuclear market: historic acquisitions considered for estimations. The cash amounts have been converted with a GDP deflator

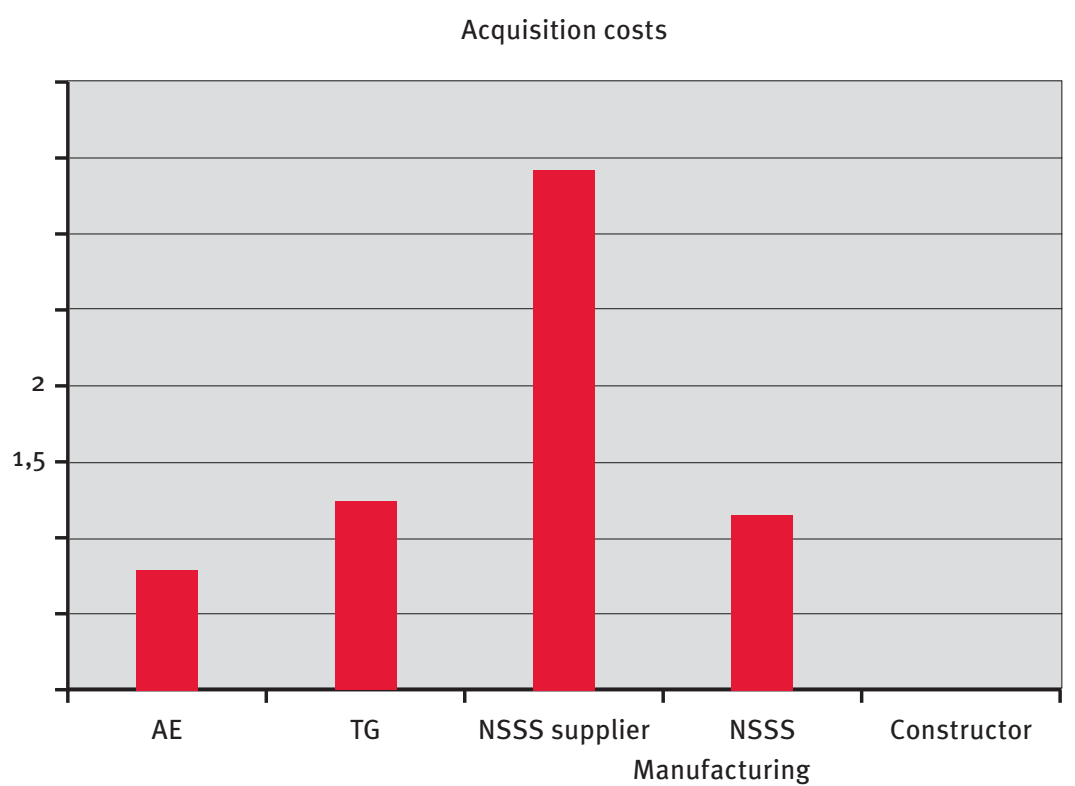

Figure 10 Mean acquisition costs

house, the licenser, took part in Framatome establishment in 1958 along with other local companies (Boulin and Boiteux, 2000). Referring to the French Case Study, it is possible to estimate about 7 NPP projects (including the Chooz prototype) needed to Framatome to obtain self-reliance. In 1978 Westinghouse left Framatome shareholding, while the license expired in 1982 (Boulin and Boiteux, 2000). According to (Roche, 2011), companies providing NSSS design and manufacturing were already self-reliant at that date.
A strong involvement of French government, thanks to relevant shareholdings in key nuclear companies (EDF, Framatome), influenced the whole Technology Transfer process (Leny Pellissier-Tanon, 1984) (Golay, Saragossi and Willefert, 1977). Japanese case study shows a shorter lead-time to reach self-reliance in NSSS design and manufacturing for both PWR and BWR technologies (see Table 6 and Table 7). This peculiarity is influenced and connected to the strong governmental support to national nuclear industry for the fossil-fuel independence (WNA, 2011 a) and the R\&D efforts by Hitachi, Toshiba and MHI. US' case study gives no useful information. U.S. companies (WH and GE - Table 8 and Table 9) were the "progenitors" of BWR and PWR technologies, developed during and after the WWII, thanks to strong R\&D investments (WNA, 2011 b). In addition ASME certifications are needed to supply NSSS components (Voutsinos, 2009) (ONE/TUV/ $B V$, 2009). The cost estimating for the NSSS Technology Transfer, similarly to 


\begin{tabular}{|c|c|c|c|c|c|c|c|c|}
\hline $\begin{array}{c}\text { Overnight } \\
\text { Cost USD/ } \\
\text { kWe }\end{array}$ & Country & Tech. & MWe & $\begin{array}{c}\text { Total Cost } \\
\text { (million \$) }\end{array}$ & $\begin{array}{c}\text { NSSS } \\
\text { (million \$) }\end{array}$ & $\begin{array}{c}\text { TG } \\
\text { (million \$) }\end{array}$ & $\begin{array}{c}\text { Constructor } \\
\text { (million \$) }\end{array}$ \\
\hline 3009 & Jap & ABWR & 1330 & 4,002 & 1,027 & 863 & 709 & 680 \\
\hline 3382 & USA & PWR & 1350 & 4,566 & 1,172 & 984 & 809 & 776 \\
\hline 3860 & Fra & EPR & 1630 & 6,292 & 1,614 & 1,357 & 1,115 & 1,070 \\
\hline 1556 & Kor & APR1400 & 1343 & 2,090 & 536 & 451 & 370 & 355 \\
\hline 1976 & Kor & OPR1000 & 954 & 1,885 & 484 & 406 & 334 & 320 \\
\hline
\end{tabular}

Table 11 Contract values' subdivision: estimates (NEA, 2000) (IEA \& NEA, 2010)

AE, shows a lack of documentation which doesn't permit any further analysis.

\section{TG supplier}

NSSS suppliers have a common control over TG prime contracts, reducing the importance and interest of this role for the purpose of this paper. In Korea local companies developed TG suppliers' skills through Technology Transfer process, similarly to the NSSS design and manufacturing (Table 5). In France Alstom was committed with TG supplies since the first NPPs (Table 8), while in Japan the same occurrence regarded MHI for PWR technology. Conventional TG suppliers can operate in nuclear business, since PWR technology has no radioactive fluids flowing into the turbines (Mehta and Pappone, 2008). It is important to highlight a minimum time-to-market for TG suppliers in BWRs (such as Hitachi and Toshiba -Table 6 and Table 7), directly linked to the plant and its technological issues (Mehta and Pappone, 2008). In addition ASME certifications are needed to supply TG components (Voutsinos, 2009) (ONE/TUV/ BV, 2009).

\section{Construction}

This business appears to be the most interesting prime contractor's role for a newcomer. Most of the countries highlight a strong local participation since first NPP projects. No evidences were found to suggest relevant investments or time-to-entry for this role. A company, according to (IAEA, 2010) must be able to manage the advanced techniques re- quired by the recent tendency of NPP projects to reduce construction schedule. Thus ASME certifications are required for the installation of the equipment (Voutsinos, 2009) (ONE/TUV/BV, 2009). Nevertheless it is important to stress the importance of the "quality first" concept even for this role. (Ruuska et al., 2009) show as "Forssan Betoni”, a concrete supplier for Areva in the Olkiluoto 3 project, failing to satisfy the quality standard procured a huge cost over budget and delay to the project. A strategic factor for allowing a firm to enter in the construction market is the reactor size: smaller is the size, easier is to enter (Locatelli and Mancini, 2010). So the strategic assets for firms willing to enter in this role are not the technical capabilities, whereas the skills in quality control and quality assurance. In this role the firms receive the designs from the vendors and $A E$, so the engineering skills are not really stressed, but it is crucial the correct execution.

\section{Costs to enter the nuclear business and revenues}

The final focus is on the costs and revenues: the goal of this section is to provide an order of magnitude for the cost/ investment required to enter the nuclear market in one of the roles presented in the previous sections and its expected revenue. Table 10 includes the costs of acquisitions, mergers observed in the Case Studies' developed for the different contractual roles. The role is the key factor in this analysis: on one side the Constructor is characterized by the absence of core-technologies (beside mainly quality certifications) specific for the nuclear industry, on the opposite side the NSSS supplier is the role involving the greater investments.

Figure 10 presents the Mean acquisition costs, evaluated through data elaboration of past acquisitions. Coretechnology companies (NSSS suppliers) require the larger amount of cash, according to the companies analyzed. Table 11 and Figure 11 show the project cost estimations according to the different roles. The Construction prime contractors grant a significant share of total project's value. Despite the peculiar specialization required to design and build the elements in the nuclear area (Core, Control road, pumps, heat exchanger etc.) these items account for a minor share of the overnight cost. Most of the overnight cost is related to the Balance Of Plant (BOP) and civil works (e.g. pouring concrete). That is the reason why the "construction" can be so interesting for all the EPC companies.

\section{Conclusions: Answers to the Research Questions}

The conclusions of this paper are the answer to the research questions

Q1: Which are the drivers shaping the PDC in a nuclear power plant project?

Since the presence of a national nuclear power program enables national companies to enter the business, the government is the most influencing driver in the shaping of a NPP PDC. As showed in all the countries analyzed 
KEPCO-KHNP

(EPC)

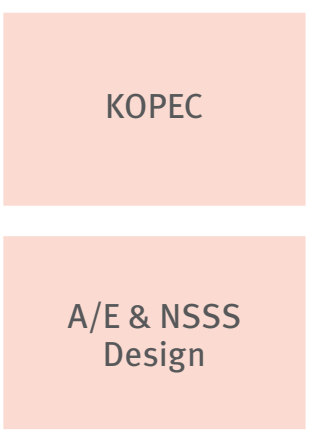

DOOSAN HEAVY

INDUSTRIES \&

CONSTRUCTION

Equipment supply (Toshiba as

subcontractor for turbines)
HYUNDAI E\&C

SAMSUNG C\&T

Nuclear

Consruction
Westinghouse

KEPCO-KPS

components not

owned by Korea

Figure 12 - Korean Consortium winning in UAE. Elaborated from (Park and Chevalier, 2010) (Berthelémy and Lévêque, 2011)

the decisions to start the nuclear power program has been taken not by single utilities, but from the "national policy makers" i.e. the national governments. The government drives also the Technology Transfer process, which is basic in order to develop a self-reliant national nuclear industry. Partnerships and alliances are significant drivers, creating opportunities for local companies in participating at NPP projects.

Q2: Which are the main barriers to enter the nuclear power plant business sector?

The support of the national government is the greatest barrier in the nuclear business. In absence of a national nuclear power program, no company can enter nuclear business as a prime contractor. Other barriers depend on the prime contractual role. Technology Transfer processes, investments and partnerships are important to overcome them.

Q3: Which are the enabling factors leading a company to proficiently enter the nuclear power plant business?

Enabling factors for companies can be summarized as: Workforce, Qualifications, Technological know-how. These three factors are required differently for prime contractual roles analyzed: in particular it is remarkable the Qualification's role (ASME Stamps and RCC-M Qualifications are broadly required in NPP projects). Qualifications are required both to manufacturing companies, to con- struction's prime contractors and NSSS suppliers.

Q4: Do exist Paths, leading to an entry in nuclear power plant PDC?

The case study methodology shows the similarities between strategic paths followed by companies. No evidence has been found of companies directly entered into international nuclear business: the importance of a national nuclear program had been remarked. Furthermore, construction companies generally entered nuclear business after experiences in international projects. NSSS suppliers and AE's prime contractors (roles involving a strong technological know-how) often entered the national nuclear business through Technology Transfer processes and efforts in R\&D during the first years after the World War II.

Q5: How much time and investment must a company face to enter nuclear power plant business? Are they different along with diverse contractual roles?

The appropriate way to evaluate required time is the number of participations in NPP projects. Different roles require different time: $A E$ and NSSS suppliers' prime contractors acquired the knowledge through a Technology Transfer process. This route took 6 to 7 NPP project participations (for French and Korean situation) for the NSSS design and manufacturing capabilities and the same for the development of AE skills. Japan developed skills of this kind in a shorter time (about 3 NPP project participations), due to its strong efforts in R\&D. Costs connected with acquisitions of companies to enter nuclear business have been analyzed through past acquisitions: NSSS suppliers' invested the higher amounts. Remarkable is that Japanese construction companies participated in national NPP projects since the beginning.

\section{Appendix: Pilot Case Study:} UAE's bid for a new NPP project As shown in (Park and Chevalier, 2010) in 2009 a Korean Consortium, led by the Korea Electric Power Corporation (KEPCO), won a \$20 billion contract to develop a civilian NPP for the UAE (one of the World's largest nuclear tenders on offer), beating French, U.S. and Japanese rivals. The Korean Consortium was selected among two other proposals, made by Areva and General ElectricHitachi, in a decision process strongly affected by price. Figure 12 shows the Korean Consortiums' components in details.

The Korean Standardized Nuclear Reactors (KSNR), leading to the current OPR-1000 and APR-1400 nuclear reactors produced by Korea, are based on the U.S. Combustion Engineering (now Westinghouse) reactor called System $80+$. Korea is embarking on a process 
to become completely self-sufficient for the technologies still supplied by Westinghouse, which include the nuclear design code, the reactor coolant pumps and the man-machine interface systems. This statement highlights the macro-importance of partnerships and strategic alliances in nuclear power business, along with the Technology Transfer process. The Case Study diffusely bases on scientific papers, analyzing reasons that led to the Korean victory. Costs, referring to (Berthelémy and Lévêque, 2011), were one of the most important. The APR1400, at the time in construction phase, in Korea had an overnight cost estimate about $60 \%$ less expensive than the EPR in construction in France by Areva, and 32\% less expensive than the EPR and AP1000 in construction in China. The paper then defines other parameters important for the winning bid: shutdown performances and contract risks allocation are examples of effective factors.

\section{References}

Ahn, J.H. and Han, K.I. (1998) 'Korean Experience

in self-reliance for nuclear power technology

(a case study in the Republic of Korea)',

IAEA - Nuclear power in developing countries:

its potentatial role and strategies for its

deployment, pp. 200-209.

Alstom (2011) History of Alstom, [Online], Available: HYPERLINK “http://www.alstom. com/static/alstom-history/main_fr.html” http://www.alstom.com/static/alstomhistory/main_fr.html.

ArabNews (2011) 16 Saudi nuclear reactors to cost \$30o billion, 01 June, [Online],

Available: HYPERLINK “http://arabnews. com/saudiarabia/article445147.ece” http:// arabnews.com/saudiarabia/article445147.ece .

AREVA (2009) 2009 Reference Document.

ASME (2011 a) American Society of Mechanical Engineers, [Online], http://www.asme.org/ . ASME (2011 b) Nuclear Component Certification, http://www.asme.org/kb/standards/ certification---accreditation/productcertification/nuclear-component-certificationprogram.

Barrè, B. (2008) 'Survey of Nuclear Politics'.

Bechtel (2011) 1945 - 1959: Bringing Energy to the World, [Online], Available: HYPERLINK “http://
www.bechtel.com/BAC-Chapter-3.html" http://www.bechtel.com/BAC-Chapter-3.html .

Berthelémy, M. and Lévêque, F. (2011) 'Korea nuclear exports:why did Korea win the UAE tender? Will Korea achieve his goal of exporting 80 nuclear reactors by 2030?'.

Boulin, P. and Boiteux, M. (2000) 'L'aventure nucléaire en France: grande et petite histoire', Les amis de L'Ecole de Paris.

Choi, S., Jun, E., Hwang, I.S., Starz, A., Mazour, T., Chang, S.H. and Burkart, A.R. (2009) 'Fourteen lessons learned from the successful nuclear power program of the Republic of Korea', Energy Policy.

Collingridge, D. (1984 a) 'Lessons of nuclear power, French “success” and the breeder', Energy Policy, pp. 189-200.

Collingridge, D. (1984) 'Lessons of nuclear power, US and UK history’, Energy Policy, March, pp. 46-67.

David, P.A. and Rothwell, G.S. (1994) 'Measuring standardization: An application to the American and French nuclear power industries', European Journal of Political Economy, pp. 291-308.

Davis, L.W. (2011) 'Prospects for U.S. Nuclear Power after Fukushima'.

Energybiz (2007) 'Bechtel Sees Nuclear Surge', Energybiz Magazine, pp. 70-72.

Financial Times (2006) Toshiba sees boost from Westinghouse buy, 17 October, [Online], Available: HYPERLINK “http://www.ft.com/ intl/cms/s/o/99a633d6-5ddf-11db-82d4o000779e2340.html” http://www.ft.com/ intl/cms/s/o/99a633d6-5ddf-11db-82d4oooo779e2340.html.

Financial Times (2009) Doosan Heavy moves for Skoda Power, 23 June, [Online], Available: HYPERLINK “http://www.ft.com/intl/cms/ s/o/8aoe18ao-5f8d-11de-93d1-00144feabdco. html” \l “axzz1Poly4fEd” http://www.ft.com/ intl/cms/s/o/8aoe18ao-5f8d-11de-93d100144feabdco.html\#axzz1Poly4fEd .

Flyvbjerg, B. (2006) 'Five Misunderstandings About Case-Study Research', Qualitative Inquiry, pp. 219-245.

Foratom (2011) New build plans go ahead in UK and Poland, 18 May, [Online], Available: HYPERLINK “http://www.foratom.org/ebulletin-tout-1378/other-articles-tout-1385/823new-build-plans-go-ahead-in-uk-and-poland. html" http://www.foratom.org/e-bulletintout-1378/other-articles-tout-1385/823-newbuild-plans-go-ahead-in-uk-and-poland.html . Golay, M.W., Saragossi, I.I. and Willefert, J.M. (1977) Comparative analysis of United States and French nuclear power plant siting and construction regulatory policies and their economic consequences, DOE.

Grubler, A. (2010) 'The costs of the French nuclear scale-up: A case of negative learning by doing', Energy Policy, pp. 5174-5188.

Highbeam (2000) Doosan-led Consortium buys controlling stake in Korea Heavy Industries Co., 12 December, [Online], Available: HYPERLINK “http://www.highbeam.com/ doc/1G1-67870730.html” http://www. highbeam.com/doc/1G1-67870730.html . Hitachi (2008 a) Nuclear Experience of HitachiGE Nuclear Energy Ltd., 28 Mar, [Online], Available: HYPERLINK “http://www.uai.cl/ energia/images/presentaciones_sem/ot_ge_ hitachi_christian_blessing.pdf" http://www. uai.cl/energia/images/presentaciones_sem/ ot_ge_hitachi_christian_blessing.pdf.

Hitachi-GE (2010 a) Construction Evolution Hitachi-GE Nuclear Energy, Ltd., [Online], Available: HYPERLINK “http://www.hitachihgne.co.jp/en/activities/plant_construction/ construction/method/index.html" http:// www.hitachi-hgne.co.jp/en/activities/ plant_construction/construction/method/ index.html,

Hitachi-GE (2010 b) Shortning Construction Period - Hitachi-GE Nuclear Energy, Ltd., [Online], Available: HYPERLINK “http://www.hitachihgne.co.jp/en/activities/plant_construction/ time/index.html" http://www.hitachi-hgne. co.jp/en/activities/plant_construction/time/ index.html .

IAEA (1988) Nuclear Power Project Management: $A$ Guidebook, Available: http://www-pub.iaea.org/ $\mathrm{mtcd} /$ publications/pdf/trs1/trs279_web.pdf.

IAEA (1999) Economic Evaluation of Bids fo Nuclear Power Plants, Available: http://www-pub.iaea. org/MTCD/publications/PDF/TRS396_scr.pdf.

IAEA (2000) Nuclear Power in Developing Countries: its Potential Role and Strategies for its Development, Vienna: IAEA.

IAEA (2004) Construction and commissioning experience of evolutionary water cooled nuclear power plants, Apr, [Online], Available: HYPERLINK “http://www-pub.iaea.org/MTCD/ publications/PDF/te_1390_web.pdf” http:// www-pub.iaea.org/MTCD/publications/PDF/ te_1390_web.pdf.

IAEA (2007) Managing the first nuclear power plant project, May, [Online], Available: HYPERLINK "http://www-pub.iaea.org/MTCD/publications/ PDF/te_1555_web.pdf” http://www-pub.iaea. org/MTCD/publications/PDF/te_1555_web.pdf. IAEA (2010) Project Management of NPP including Construction. 
IEA \& NEA (2010) Projected Costs of Generating Electricity.

Industcards (2011 a) Industcards Website, [Online], Available: HYPERLINK “www. industcards.com" www.industcards.com . Industcards (2011 b) Nuclear Power Plants in South Korea, [Online], Available: HYPERLINK "http://www.industcards.com/nuclear-skorea.htm" http://www.industcards.com/ nuclear-s-korea.htm .

Industcards (2011 c) Nuclear Power Plants in Japan, [Online], Available: HYPERLINK “http://www. industcards.com/nuclear-japan.htm" http:// www.industcards.com/nuclear-japan.htm .

Industcards (2011 d) Nuclear Power Plants in the Carolinas, [Online], Available: HYPERLINK "http://www.industcards.com/nuclear-uscarolinas.htm" http://www.industcards.com/ nuclear-us-carolinas.htm .

Industcards (2011 e) Nuclear Power Plants in Indiana \& Michigan, [Online], Available: HYPERLINK “http://www.industcards. com/nuclear-us-in-mi.htm" http://www. industcards.com/nuclear-us-in-mi.htm . Industcards (2011 f) Nuclear Plants in Kansas, Missouri and Nebraska, [Online], Available: HYPERLINK “http://www.industcards.com/ nuclear-us-ks-mo-ne.htm” http://www. industcards.com/nuclear-us-ks-mo-ne.htm . Industcards (2011 g) Nuclear Plants in the Northeast USA, [Online], Available: HYPERLINK "http://www.industcards.com/nuclear-usnortheast.htm" http://www.industcards.com/ nuclear-us-northeast.htm .

Industcards (2011 h) Nuclear Power Plants in Oregon \& Washington, [Online], Available: HYPERLINK “http://www.industcards. com/nuclear-us-or-wa.htm" http://www. industcards.com/nuclear-us-or-wa.htm . Industcards (2011 i) Nuclear Power Plants in Pennsylvania, [Online], Available: HYPERLINK “http://www.industcards.com/nuclear-us-pa. htm" http://www.industcards.com/nuclearus-pa.htm .

Industcards (2011 l) Nuclear Power Plants in the South Central USA, [Online], Available: HYPERLINK "http://www.industcards.com/ nuclear-us-south-central.htm" http://www. industcards.com/nuclear-us-south-central.htm .

Industcards (2011 m) Nuclear Power Plants in California, [Online], Available: HYPERLINK “http://www.industcards.com/nuclear-us-ca. htm" http://www.industcards.com/nuclearus-ca.htm .

Industcards (2011 n) Nuclear Power Plants in Illinois, [Online], Available: HYPERLINK "http://www.industcards.com/nuclear-us-il. htm" http://www.industcards.com/nuclearus-il.htm .

Industcards (2011 0) Nuclear Power Plants in lowa, Minnesota, South Dakota \& Wisconsin, [Online], Available: HYPERLINK “http://www. industcards.com/nuclear-us-ia-mn-sd-wi.htm” http://www.industcards.com/nuclear-us-iamn-sd-wi.htm .

Industcards (2011 p) Nuclear Plants in New York, [Online], Available: HYPERLINK “http://www. industcards.com/nuclear-us-ny.htm” http:// www.industcards.com/nuclear-us-ny.htm .

JAIF (2003) Nuclear Power Plant in The World 2003, Tokyo: Japan Atomic Industrial Forum.

KEPCO E\&C (2011) History, [Online], Available: HYPERLINK “http://www.kepco-enc. com/English/sub.asp?Mcode=A020020" http://www.kepco-enc.com/English/sub. asp? Mcode=A020020 .

Leny Pellissier-Tanon, J.C.A. (1984) 'Standardized French PWR Programs and the application of mechanical analysis', Nuclear Engineering and Design, pp. 117-125.

Lesbirel, S.H. (1990) 'Implementing nuclear energy policy in Japan: Top-down and Bottomup perspectives', Energy Policy, pp. 267-282.

Locatelli, G. and Mancini, M. (2010) 'Risk management in a mega-project: the Universal EXPO 2015 case', International Journal of Project Organisation and Management, vol. 2, no. 3, pp. 236 - 253.

Locatelli, G. and Mancini, M. (2010) 'The role of the reactor size for an investment in the nuclear sector: an evaluation of not-financial parameters', Progress in Nuclear Energy, vol. 53, no. 2, pp. 212-222.

Locatelli, G. and Mancini, M. (2012) ‘Looking back to see the future: Building nuclear power plants in Europe', Construction Management and Economics, vol. 30, no. 8, pp. 623-637.

Mehta, H.S. and Pappone, D.C. (2008) Companion guide to the ASME Boiler \& Pressure Vessel Code: New Generation of BWRs.

MPR (2004) Application of Advanced Construction Technologies to New Nuclear Power Plants. MPR (2005) DOE NP2010 Nuclear Power Plant Construction Infrastructure Assessment.

MPR (2005) DOE NP2010 Nuclear Power Plant Construction Infrastructure Assessment.

MPR (2010) Viability of Developing a US Domestic Source for Large Forgings for Nuclear Power Plants - A Cost/Benefit Study.

NEA (2000) Reduction of Capital Costs of Nuclear Power Plants.

Nuclear Power Daily (2011) Siemens says received EUR1.62 bn for Areva NP stake, 10 April, [Online], Available: HYPERLINK “http:// www.nuclearpowerdaily.com/reports/ Siemens_says_received_EUR1point62bn_ for_Areva_NP_stake_999.html” http://www. nuclearpowerdaily.com/reports/Siemens_ says_received_EUR1point62bn_for_Areva_NP_ stake_999.html.

ONE/TUV/BV (2009) ASME Code Seminare, Available: http://www.bureauveritas.it/wps/ wcm/connect/1d8cf5004e884639bcc4bf7cc78 c87dd/KOELBL_ATTI_Nucleare_iBV63.pdf?MO $\mathrm{D}=\mathrm{AJPERES} \& C A C H E I D=1 \mathrm{~d} 8 \mathrm{cf} 5004 \mathrm{e} 884639 \mathrm{bcc}$ $4 \mathrm{bf} 7 \mathrm{cc} 78 \mathrm{c} 87 \mathrm{dd}$.

Park, C.T. (1992) 'The experience of nuclear power development in the Republic of Korea'.

Park, K.C. and Chevalier, F. (2010) 'The Winning Strategy of the Late-Comer: How Korea Was Awarded the UAE Nuclear Power Contract', International Review of Business Research Papers, 2 July, pp. 221-238.

Pickett, S.E. (2002) ‘Japan's nuclear energy policy: from firm commitment to difficult dilemma addressing growing stocks of plutonium, program delays, domestic opposition and international pressure', Energy Policy, pp. 1337-1355.

Plantè, J. (1998) 'The French experience in nuclear energy: reasons for success', IAEA - Nuclear power in developing countries: its potentatial role and strategies for its deployment.

Project Management Institute (2000) $A$ Guide to the Project Management Body of Knowledge (PMBOK guide), Newtown Square, Pennsylvania USA.

Roche, B. (2011) The French nuclear program: EDF's experience, [Online], Available: HYPERLINK “http://apw.ee.pw.edu.pl/ tresc/-eng/o8-FrenchNucleamProgram.pdf" http://apw.ee.pw.edu.pl/tresc/-eng/o8FrenchNucleamProgram.pdf .

Ruuska, I., Ahola, T., Artto, K., Locatelli, G. and Mancini, M. (2011) 'new governance approach for multi-firm projects: Lessons from Olkiluoto 3 and Flamanville 3 nuclear power plant projects', International Journal of Project Management, vol. 29, no. 6, pp. 647-66o.

Ruuska, I., Artto, K., Aaltonen, K. and Lehtonen, P. (2009) 'Dimensions of distance in a project network: Exploring Olkiluoto 3 nuclear power plant project', International Journal of Project Management, vol. 2, no. 27, pp. 142-153.

S\&W (2011) Stone \& Webster, [Online], Available: HYPERLINK “http://www.nukework.com/" http://www.nukework.com/ .

Scientech (2010) Commercial Nuclear Power Plants, Mar, [Online], Available: HYPERLINK “http://scientech.cwfc.com/company/ spokes/PDF/cnpp25.pdf" http://scientech. 
cwfc.com/company/spokes/PDF/cnpp25.pdf .

Shaw (2011) History - The Shaw Group, [Online], Available: HYPERLINK "http://www.shawgrp. com/about/history” http://www.shawgrp. com/about/history .

Sung, C.S. and Hong, K.H. (1999) 'Development process of nuclear power industry in a developing country: Korean experience and implications', Technovation, pp. 305-316.

The Guardian (2006) Bouygues buys Alstom stake, 28 April, [Online], Available: HYPERLINK "http://www.guardian.co.uk/business/2006/ apr/28/france.internationalnews" http:// www.guardian.co.uk/business/2006/apr/28/ france.internationalnews

The New York Times (2000) Shaw Group wins the bidding for Stone \& Webster, 8 July, [Online], Available: HYPERLINK “http:// www.nytimes.com/2000/07/08/business/ company-news-shaw-group-wins-the-biddingfor-stone-webster.html" http://www.nytimes. com/2000/07/08/business/company-newsshaw-group-wins-the-bidding-for-stonewebster.html.

Toshiba (2006) The acquisition of Westinghouse, o8 Feb, [Online], Available: HYPERLINK “http://www.toshiba.co.jp/about/ir/en/ library/pr/pdf/tpr20060208e.pdf” http:// www.toshiba.co.jp/about/ir/en/library/pr/ pdf/tpr20060208e.pdf .

Toshiba America Nuclear Energy (2010) Construction experience in Japan, 20 Aug, [Online], Available: HYPERLINK “http:// www.iaea.org/NuclearPower/Downloads/ Technology/meetings/2010-August-19_20_ WS/02.01.Toshiba.pdf" http://www.iaea. org/NuclearPower/Downloads/Technology/ meetings/2010-August-19_20_WS/02.01. Toshiba.pdf .

Valentine, S.V. and Sovacool, B.K. (2010) 'The socio-political economy of nuclear power development in Japan and South Korea', Energy Policy, pp. 7971-7979.

Voutsinos, C.M. (2009) Qualifications needed to design, construct and manufacture nuclear systems and equipment, Available: http:// www.computare.org/Support\%2odocuments/ Guests/Computare\%20PDF\%2oWestern\%20 Focus\%20Seminar/Papers_Handouts/ $\mathrm{WF}_{4} / 2 \% 20-\% 20$ Voutsinos $\% 20 \% 20$ Qualifications\%2009_05_28.pdf [28 Feb 2011].

WNA (2011 a) Nuclear Power in Japan / Japanese Nuclear Energy, 30 Mar, [Online], Available: HYPERLINK “http://www.world-nuclear.org/ info/inf79.html” http://www.world-nuclear. org/info/inf79.html .
WNA (2011 b) Nuclear Power in the USA, Mar, [Online], Available: HYPERLINK “http://www. world-nuclear.org/info/inf41.html” http:// www.world-nuclear.org/info/inf41.html .

WNA (2011 c) Heavy Manufacturing of Power Plants, [Online], Available: HYPERLINK “http:// www.world-nuclear.org/info/inf122_heavy_ manufacturing_of_power_plants.html”http:// www.world-nuclear.org/info/inf122_heavy_ manufacturing_of_power_plants.html .

Yin, R.K. (2003) Case Study Research - Design and Methods - Third Edition, SAGE Publications. 